\title{
Adjunctive Versus Monotherapeutic Treatment for Schizophrenia: Addressing Antipsychotic Side Effects
}

To The Editor: In the article by Joo-Cheol Shim, M.D., Ph.D., et al., published in the September 2007 issue of the Journal, aripiprazole was added to haloperidol to evaluate the beneficial effects on haloperidol-induced hyperprolactinemia. The authors pointed out that switching is "not always possible in clinical practice, especially if the patient has responded well to the antipsychotic that produced the hyperprolactinemia" (1, p. 1404). The addition of aripiprazole significantly decreased prolactin levels and improved negative symptoms, sleep, and extrapyramidal side effects. The authors attributed these effects to aripiprazole's unique mechanism(s) of action (2). We do not take issue with the scientific merit of this study but are concerned with the clinical implications, specifically the apparent promotion and justification of the adjunctive use of aripiprazole.

Well-controlled clinical studies have not supported the use of antipsychotic polypharmacy, and this practice has been associated with increased adverse effects $(3,4)$, premature death (5), and unnecessary economic demands (6). Good clinical practice argues for the fewest medications possible and, in the case of treatment with antipsychotics, advocates for the adjunctive use of antipsychotics as a last resort (7). As a class, the newer antipsychotics have afforded us advantages in decreasing extrapyramidal symptoms, lowering prolactin

Am J Psychiatry 165:3, March 2008 
levels, and reducing the risk of tardive dyskinesia $(2,7,8)$. Furthermore, contrary to what is stated in the article by Dr. JooCheol Shim et al., switching antipsychotic drugs, including a switch from haloperidol to aripiprazole, has previously been shown to be safe and effective (9).

\section{References}

1. Shim J-C, Shin JG, Kelly DL, Jung DU, Seo YS, Liu KH, Shon JH, Conley RR: Adjunctive treatment with a dopamine partial agonist, aripiprazole, for antipsychotic-induced hyperprolactinemia: a placebo-controlled trial. Am J Psychiatry 2007; 164: 1404-1410

2. Mamo D, Graff A, Mizrahi R, Shammi CM, Romeyer F, Kapur S: Differential effects of aripiprazole on $\mathrm{D}_{(2)}, 5-\mathrm{HT}_{(2)}$, and $5-\mathrm{HT}_{(1 \mathrm{~A})}$ receptor occupancy in patients with schizophrenia: a triple tracer PET study. Am J Psychiatry 2007; 164:1411-1417

3. Honer WG, Thornton AE, Chen EY, Chan RC, Wong JO, Bergmann A, Falkai P, Pomarol-Clotet E, McKenna PJ, Stip E, Williams R, MacEwan GW, Wasan K, Procyshyn R: Clozapine alone versus clozapine and risperidone with refractory schizophrenia. N Engl J Med 2006; 354:472-482

4. Duggal HS: Aripiprazole-olanzapine combination for treatment of schizophrenia. Can J Psychiatry 2004; 49:151

5. Waddington JL, Youssef HA, Kinsella A: Mortality in schizophrenia: antipsychotic polypharmacy and absence of adjunctive anticholinergics over the course of a 10-year prospective study. Br J Psychiatry 1998; 173:325-329

6. Stahl SM, Grady MM: High-cost use of second-generation antipsychotics under California's Medicaid program. Psychiatr Serv 2006; 57:127-129

7. Stahl SM: Focus on antipsychotic polypharmacy: evidencebased prescribing or prescribing-based evidence? Int J Neuropsychopharmacol 2004; 7:113-116

8. Remington G, Saha A, Chong SA, Shammi C: Augmenting strategies in clozapine-resistant schizophrenia. CNS Drugs 2006; 20: 171

9. Kasper S, Lerman MN, McQuade RD, Saha A, Carson WH, Ali M, Archibald D, Ingenito G, Marcus R, Pigott T: Efficacy and safety of aripiprazole vs haloperidol for long-term maintenance treatment following acute relapse of schizophrenia. Int J Neuropsychopharmacol 2003; 6:325-337

MONICA HAZRA, B.Sc. Phm, R.Ph.

DAVID C. MAMO, M.D., M.SC. GARY REMINGTON, M.D., PH.D., F.R.C.P.C. Toronto, Ontario, Canada

Dr. Remington has received research funding from NARSAD, the Stanley Medical Research Institute, Novartis, and Merck (Germany). Drs. Hazra and Mamo report no competing interests. 